Journal of Southeast Asian

2014

\title{
A Change after Coming Back from the Death's Door
}

Kyaw Kyaw Lwin

University of Minnesota

Follow this and additional works at: https://docs.lib.purdue.edu/jsaaea

\section{Recommended Citation}

Lwin, Kyaw Kyaw (2014) "A Change after Coming Back from the Death's Door," Journal of Southeast Asian American Education and Advancement. Vol. 9 : Iss. 1, Article 6.

DOI: 10.7771/2153-8999.1081

Available at: https://docs.lib.purdue.edu/jsaaea/vol9/iss1/6

This document has been made available through Purdue e-Pubs, a service of the Purdue University Libraries. Please contact epubs@purdue.edu for additional information.

This is an Open Access journal. This means that it uses a funding model that does not charge readers or their institutions for access. Readers may freely read, download, copy, distribute, print, search, or link to the full texts of articles. This journal is covered under the CC BY-NC-ND license. 


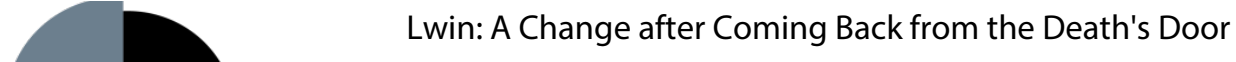 JSAAEA Journal of Southeast Asian American Education \& Advancement}

Volume 9 (2014)
WWW.JSAAEA.org

\section{A Change after Coming Back from Death's Door}

\author{
By \\ Kyaw Kyaw Lwin \\ University of Minnesota
}

A peer-reviewed

scholarly journal

published by the

National Association

for the Education \&

Advancement of

Cambodian, Laotian,

and Vietnamese

Americans (NAFEA)

Kyaw Kyaw Lwin, a graduate of Humboldt High School and a current student at the University of Minnesota, barely escaped death in Minnesota's frigid climate. One of his first experiences in America changed Kyaw Kyaw's life. All the struggles and hardships of his second day in in the United States and Minnesota inspired him to work harder. He strived through high school and now continuing his education at the University of Minnesota.

When he was 13 years old, Kyaw Kyaw Lwin lost his way home on his second day in Minnesota. It was cold and he was without a coat. He had slept over at his cousin Tun's house on the first day, and woke up really early in the morning due to his lack of adjustment to day and night time in the United States. Thinking that he knew how to get home, he walked home alone without waking anyone up. "I made an early wrong turn, and that was when it started. Every street looks like my home street," he said. He tried to follow every street that looked like his home street, and he got farther and farther from his home.

After a couple of hours, he felt the frostbite on his fingertips and toes, and he started to realize that he was lost. All the stereotypes that he knew or heard about American made it hard for him to decide who to ask. And on top of that, he was shy and didn't know English, so he was helpless. He finally found an innocent looking old lady, who was shoveling snow by her house. He wanted to ask for help, but he didn't have confidence to talk to the stranger. "I walked back and forth in front of her about six or seven times and good that thing that she talked to me first. I don't think I had confidence to start the conversation if she hadn't started," he said.

The old lady asked him a few questions such as: who, what, where, and when. He told her that his name is Kyaw Kyaw. With his very little English he replied to her that he was born in Burma, and he came from Thailand. Her expression on his last answer surprised him. "And when I told her that I am Karen, She acted as if I am some scary or unwanted person, like a criminal," he said. The old lady turned her back on him and walked back inside her house. "I really needed a placed to warm myself, I was freezing. And when I tried to follow her, she said, 'don't follow me, my dog doesn't like boys,'" he said. He thought she didn't want a stranger in her house, so he waited helplessly about 10 to 15 minutes outside. But nothing changed, he didn't see any movement from the neighborhood or her house area, so he moved on.

He kept on searching for a way home and ended up in front of the library. "I didn't know it was library at that time," he said. There were a lot of people by the large street, so he thought it was safe to ask for help from people there. He asked a man, who was in hurry, for help. The man told him that he is about one or two blocks away from his house. The man only pointed in the

\section{@)}

SORERIGHISRESERVEDReaders are free to copy, display, and distribute this article, as long as the work is attributed to the author(s) and the Journal of Southeast Asian American Education \& Advancement, it is distributed for noncommercial purposes only, and no alteration or transformation is made in the work. More details of this Creative Commons license are available at http://creativecommons.org/licenses/by-nc-nd/3.0/. All other uses must be approved by the author(s) or JSAAEA. 
direction he thought Lwin's house would be and left. That didn't help a helpless little boy. So he tried to go back to the way that he came.

Six hours later, Lwin lost hope. "I thought this is it. The flow of my blood within my body is slowing down. And the blood in my legs and arms seemed to be stop, but my life force was quite strong," Lwin said. He kept on walking, and saw a woman with her son on the playground. He really wanted to ask for help, and hoped that she could help him. "Before I asked, I walked around the playground about three or four times because I didn't have confident to talk to her, and I didn't know how to ask help. Clearly, the first lady ran away from me," he said.

"I walked up to her and said, 'I need help, I don't know home," said Lwin. The woman asked him about where he lives, and he replied, "I don't know." She asked him of someone to contact, and he replied, "I don't know." Then, he started talking to her about his cousin, Tun. "I said, 'do you know Tun? He Karen, and do New Year,' but she doesn't seem to have any clue about Karen," Lwin said. So, she asked him to think of where he lives close by, the buildings that are around his house. He replied, "I don't know." Then, he finally remembered of an "M." "McDonald's," he said. She took him to the first McDonalds, and it wasn't it. "Another," he said. She took him to the second McDonald's, and it wasn't it either. "Another," he said. She took him to the third and fourth, and it wasn't still the right one either. "I thought there was only one McDonald's. And I thought, 'where all these McDonald's came from?'” he said. So she took him to a place where people take Minnesota State ID cards.

The woman talked to the people working there. Then they took them both into a room. There was another woman in there and she started to question him. "I had no clue what they were talking about," he said. Then the woman started to question him slowly word by word. He answered the best of his skill. Then about 30 minutes later a police officer came in and took him home. "My body was white as a death, like a dead man coming out of a fridge. I barely escaped death," he said.

The experience changed Lwin's life. "It was hard to live our lives where people don't know about us. I wanted people to know about Karen. We might be just a minority group, but I want the whole world to know about us, so my people won't have to experience the helplessness like me," said Lwin. Now he is a part of Karen Culture Organization of Minnesota (KCOM). The KCOM group has the same values and perspective as him. Lwin strived to succeed all through high school. He was top four in his grade, and scored the highest in the state of Minnesota in MCA math. And now he is working toward his dream at the University of Minnesota, with a degree in business administration and a minor in engineering.

\section{About the Author}

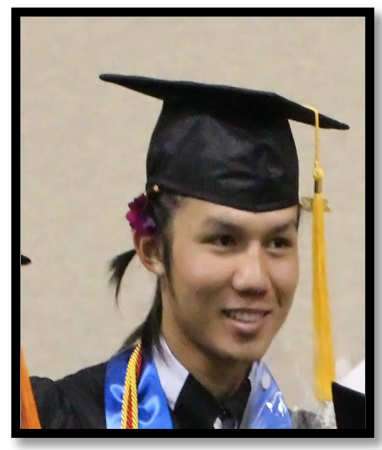

Kyaw Kyaw Lwin was born in Burma, but grew up in Thailand. He is Karen, a small ethnic group from Burma. He arrived in the United States in 2008 as a refugee. He is currently attending the University of Minnesota pursing degrees in Actuarial Science and Engineering. He is an active member of the Karen Culture Organization of Minnesota (KCOM). 


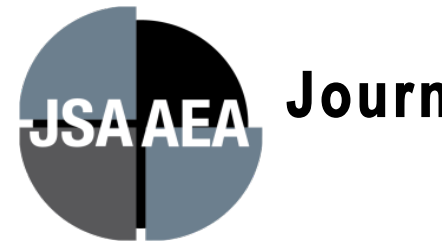

Volume 9 (2014)
WWW.JSAAEA.org

\section{Editor}

Dr. Wayne E. Wright

University of Texas at San Antonio

Associate Editors

Dr. Chhany Sak-Humphry

University of Hawaii at Manoa

Dr. Phitsamay Sychitkokhong Uy

University of Massachusetts, Lowell

\section{Book Review Editor}

Dr. Vichet Chhuon

University of Minnesota

\section{Creative Works Editor}

Bryan Thao Worra

Lao Assistance Center

Special Advisor

Gregory Green

Curator, Echols Collection on Southeast Asia, Cornell University Library

\section{Journal Manager}

Yeng Yang

University of Texas at San Antonio

\section{Editorial Assistant}

Matthew Kraft

University of Texas at San Antonio
A peer-reviewed

scholarly journal

published by the

National Association

for the Education \&

Advancement of

Cambodian, Laotian,

and Vietnamese

Americans (NAFEA) 


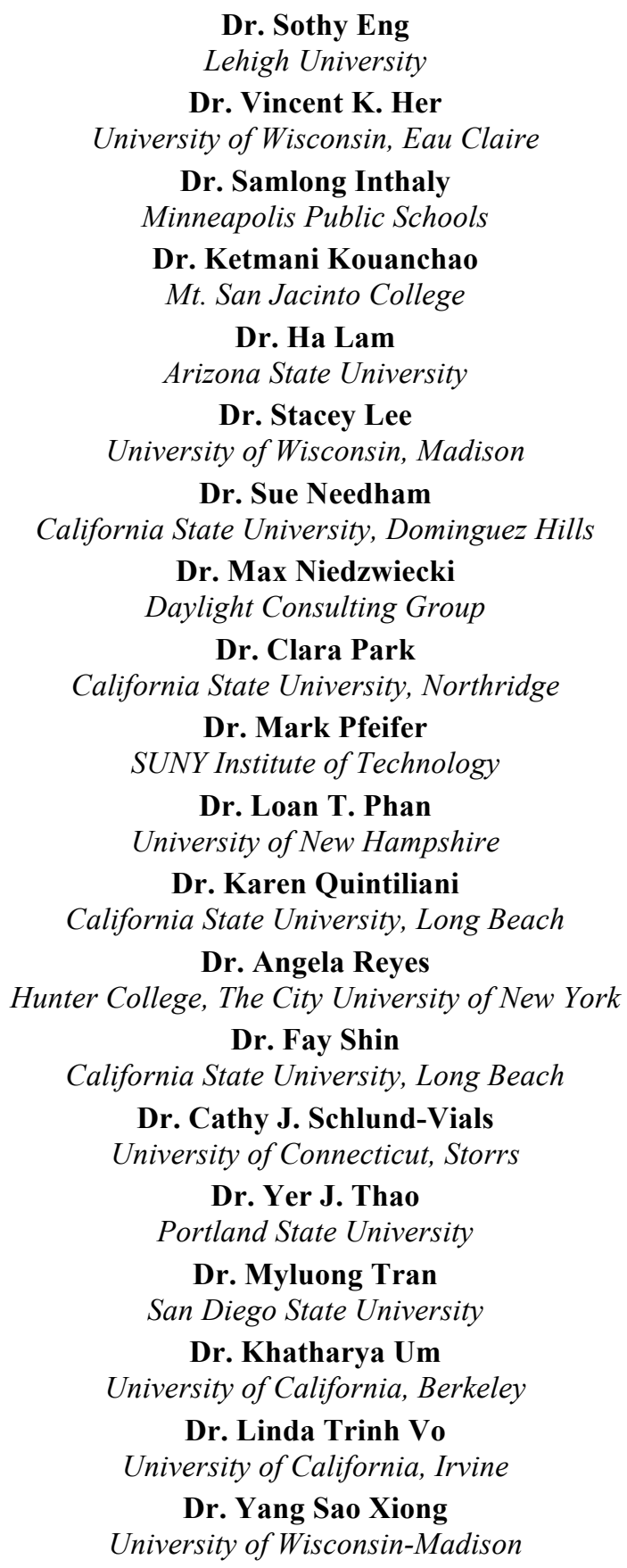

\section{Doctoral Student Editorial Review Board}

Sovicheth Boun

University of Texas at San Antonio

Keo Chea-Young

University of Pennsylvania

Dung Mao

University of Minnesota
Dr. Jeremy Hein

University of Wisconsin, Eau Claire

Dr. Nancy H. Hornberger

University of Pennsylvania

Dr. Peter Nien-Chu Kiang

University of Massachusetts, Boston

Dr. Kevin K. Kumashiro

University of Illinois, Chicago

Dr. Jonathan H. X. Lee

San Francisco State University

Dr. Monirith Ly

Texas State University-San Marcos

Dr. Bic Ngo

University of Minnesota

Dr. Leakhena Nou

California State University, Long Beach

Dr. Isabelle Thuy Pelaud

San Francisco State University

Dr. Giang Pham

University of Massachusetts

Dr. Bounlieng Phommasouvanh

Minnesota Department of Education

Dr. Kalyani Rai

University of Wisconsin, Milwaukee

Dr. Soveacha Ros

Royal University of Phnom Penh

Dr. Nancy J. Smith-Hefner

Boston University

Dr. Christine Su

Ohio University

Dr. Loan Tran

University of California, Riverside

Dr. Tinou Tran

Alief Independent School District

Dr. Silvy Un

Frost Lake Elementary School

Dr. Terrence G. Wiley

Center for Applied Linguistics

Dr. Zha Blong Xiong

University of Minnesota 
Ravy Lao

University of California, Santa Barbara

Thien-Huong Ninh

University of Southern California

Malaphone Phommasa

University of California, Santa Barbara

Alisia Tran

University of Minnesota

Anna H. Yang

University of Georgia
Minh Mai

University of Wisconsin-Madison

Hoa Nha Nguyen

Boston College

Vanna Som

Harvard University

Krissyvan Truong

Claremont Graduate University

Lesley Yang

University of Minnesota 